ECONOMICS

\title{
To Close the Gap
}

\section{Charles I. Jones}

$\mathrm{I}$ $f$ the time since modern humans first appeared, some 200 thousand years ago, were magically compressed into a single day, the era of sustained growth in living standards would occupy only the most recent minute and a half. Prior to this emergence (around 1800), living standards were low and did not vary enormously throughout the world - perhaps by a factor of 2 according to numbers compiled by the late economist Angus Maddison (1). The emergence of modern economic growth in some parts of the world but not others has caused living standards to diverge dramatically. By the end of the 20th century, the ratio of per capita gross domestic product (GDP) in the richest countries exceeded that in the poorest by more than a factor of 50 .

Michael Spence takes this history as his point of departure in The Next Convergence: The Future of Economic Growth in a
The Next Convergence The Future of Economic Growth in a Multispeed World

by Michael Spence Farrar, Straus and Giroux, New York, 2011. 312 pp. $\$ 27, £ 17.99$ ISBN 9780374159757. either facilitate or hinder growth in coming decades: globalization, financial investment, the Washington consensus, climate change, urbanization, politics, exchange rates volatility, information technology, and the financial crisis. (The only notable absence is a discussion of problems related to government debt, on display in Europe today and associated with rising entitlement spending in the United States in the future.) Economics does not always offer precise, unequivocal prescriptions regarding each of these topics, but having Spence as a brilliant guide, intimate with both the research and policy frontiers, is a perfect way to get up to speed.

It is impossible to summarize such a wide-ranging book in a brief review. Instead, let me discuss a few of the highlights. First, Spence emphasizes that economic growth is tied fundamentally to innovation and knowledge. Openness to international trade and globalization is one of the strongest correlates of economic growth in the data because it facilitates access to Multispeed World. Looking toward the future, he foresees a convergence between the economies of the world's rich and poor countries. That is, he believes that the current dynamics of economic growth, accompanied by the right policies and institutions, can lead to a new period of substantial catch-up by the poor countries.

Spence, a highly regarded economist at New York University's business school, shared the 2001 Nobel Prize in economics for work involving the microeconomics of imperfect information-how markets function when some participants know more than others. There is a certain distance between the author's prize-winning research in microtheory and the applied macroeconomic topics of concern in the book. That distance is closed by a combination of Spence's economic training, his decade as the dean of Stanford University's business school, and his most recent service as the chair of the independent Commission on Growth and Development (2).

The book provides a fascinating tour of the global economic issues that may

The reviewer is at the Graduate School of Business, Stanford University, 655 Knight Way, Stanford, CA 94305-4800, USA. E-mail: chad.jones@stanford.edu

anced discussion of the role of government in economic growth. Quoting the famous development economist Arthur Lewis, "governments may fail either because they do too little, or because they do too much" (3). Some kind of economic freedom is central to growth. Spence notes that Chinese economic growth was spurred when Deng Xiaoping and other reformers allowed the market mechanism to work in agriculture, permitting farmers to sell the excess of their production over their planned quotas on open markets. However, democracy is evidently not a necessary ingredient for economic success, as the example of China also indicates. Instead, what appears to be essential is a government that creates an environment in which investment by the private sector is profitable.

Lastly, Spence highlights a well-known association between urbanization and economic growth. He describes China as needing to build a new Los Angeles every year to accommodate its annual flow of 15 million people from the countryside. Yet despite three decades of such movements, more than 50 percent of China's population remains rural. The number in India is even higher, around 70 percent, and Spence suggests that India will likely experience massive urbanization in the next two decades. Echoing a point that Paul Romer has explored creatively in recent years, urban infrastructure appears to be a crucial ingredient to sustained growth (4).

In concluding, Spence acknowledges the uphill battle that economic progress faces. "Getting there from where we are now will be difficult. Political, business, and academic elites have lost credibility with the populace in many countries. We have been wrong about important characteristics of the economy that affect people's lives, and relatively insensitive to distributional issues." But engaging, intellectual treatments like this one will surely make progress easier.

\section{References}

1. A. Maddison, "Statistics on world population, GDP, and per capita GDP, 1-2008 AD" (March 2010); available at www.ggdc.net/MADDISON/oriindex.htm.

2. www.growthcommission.org.

3. W. A. Lewis, The Theory of Economic Growth (Allen and Unwin, London, 1955).

4. P. Romer, "For richer, for poorer." Prospect (London), 167 (January 2010); www.prospectmagazine. co.uk/2010/01/for-richer-for-poorer/.

10.1126/science. 1214409

\section{ENGINEERING}

\section{Low Costs and Considerable Gains}

\section{Esther M. Sternberg}

$\mathrm{F}$ ormerly subsistence economies are developing rapidly while highly developed nations are experiencing widespread unemployment and poverty. Design with the Other 90\%: Cities provides hope that both extremes can come together to help lift the underprivileged out of poverty through creative design. Organized by the Smithsonian Institution's Cooper-Hewitt National Design Museum under the direction of Cynthia Smith (the museum's curator of socially responsible design), the exhibition is at the United Nations headquartersa most appropriate venue for spotlighting design solutions that have been instituted by more than 60 projects in 23 countries around the globe. As one of the designers notes, humans need food, water, and shelter to live. The show points the way to cost-effective

The reviewer is the author of Healing Spaces: The Science of Place and Well-Being. Web site: www.esthersternberg.com 